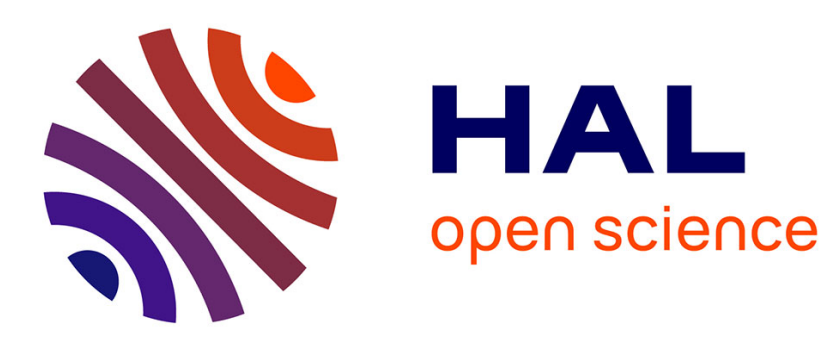

\title{
Telemedicine and mobile health with integrative medicine in developing countries
}

Bernard Kamsu-Foguem, Clovis Foguem

\section{To cite this version:}

Bernard Kamsu-Foguem, Clovis Foguem. Telemedicine and mobile health with integrative medicine in developing countries. Health Policy and Technology, 2014, vol. 3 ( $\mathrm{n}^{\circ} 4$ ), pp. 264-271. 10.1016/j.hlpt.2014.08.008 . hal-01107237

\section{HAL Id: hal-01107237 \\ https://hal.science/hal-01107237}

Submitted on 20 Jan 2015

HAL is a multi-disciplinary open access archive for the deposit and dissemination of scientific research documents, whether they are published or not. The documents may come from teaching and research institutions in France or abroad, or from public or private research centers.
L'archive ouverte pluridisciplinaire HAL, est destinée au dépôt et à la diffusion de documents scientifiques de niveau recherche, publiés ou non, émanant des établissements d'enseignement et de recherche français ou étrangers, des laboratoires publics ou privés. 


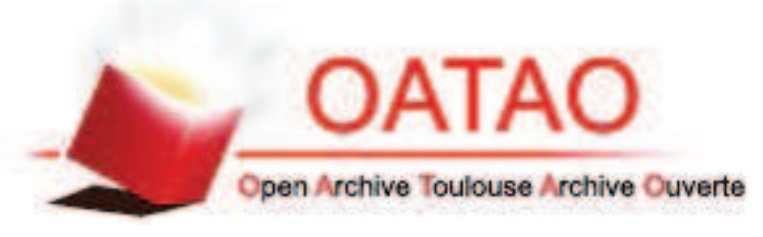

\section{Open Archive TOULOUSE Archive Ouverte (OATAO)}

OATAO is an open access repository that collects the work of Toulouse researchers and makes it freely available over the web where possible.

This is an author-deposited version published in : http://oatao.univ-toulouse.fr/ Eprints ID : 12273

To link to this article : DOI: $10.1016 /$ j.hlpt.2014.08.008

http://dx.doi.org/10.1016/j.hlpt.2014.08.008

To cite this this version : Kamsu-Foguem, Bernard and Foguem, Clovis Telemedicine and mobile health with integrative medicine in developing countries. (2014) Health Policy and Technology, vol. 3 $\left(n^{\circ} 4\right)$. pp. 264-271. ISSN 2211-8837

Any correspondance concerning this service should be sent to the repository administrator: staff-oatao@,listes-diff.inp-toulouse.fr 


\title{
Telemedicine and mobile health with integrative medicine in developing countries
}

\author{
Bernard Kamsu-Foguem ${ }^{\mathrm{a}, *}$, Clovis Foguem ${ }^{\mathrm{b}}$ \\ a Laboratory of Production Engineering (LGP), EA 1905, ENIT-INPT University of Toulouse, \\ 47 Avenue d'Azereix, BP 1629, 65016 Tarbes Cedex, France \\ ${ }^{\mathrm{b}}$ Center for Food and Taste Sciences (CSGA), UMR 6265 CNRS - UMR 1324 INRA, University of Burgundy, \\ 9 E Boulevard Jeanne d'Arc, 21000 Dijon, France \\ Available online 19 August 2014
}

\section{KEYWORDS}

Telemedicine;

Mobile health;

Complementary

healthcare;

Integrated medicine;

Collaborative knowl-

edge building

\begin{abstract}
African Home-based Care (AHC) and African Traditional Medicine (ATM) provide a number of self-sustainable primary health care workers in a rural region with the appreciation of ancestral knowledge and its contextual management. Even though most urban residents are able to afford and use conventional medicine to large extent, the implementations of modern medicine in rural areas and in poor peri-urban areas are limited. Our proposal is on how telemedicine solutions could enhance AHC and ATM practices and facilitate simultaneous delivery of both modern and traditional healthcare with evident added value to the recipients. This is indeed a fresh angle, as information and communication technologies (ICTs) could play an important role in developing countries in the management of patients and enhance quality care for patients in particular and healthcare (both traditional and modern heath systems) in general. This delivers comprehensive insights concerning the implementation on telemedicine where integrative medicine and African traditional medicine is in the back seat.
\end{abstract}

\section{Objective}

The term African Home-based Care (AHC) is used differently in different parts of Africa. In some cases it is managed by public health department and offers primary care, health promotion and prevention programs. In other cases, it is a traditional community health center that serves as the point of contact between the community members and the traditional health care provider for counseling and traditional medicine.

\footnotetext{
*Corresponding author. Tel.: +336243023 37; fax: + 33562442708 .

E-mail address: Bernard.Kamsu-Foguem@enit.fr (B. Kamsu-Foguem).
}

African Home-based Care (AHC) offers self-sustainable primary healthcare workers in a rural region with the appreciation of ancestral knowledge and its contextual management. Even though most urban residents are able to afford and use conventional medicine to a large extent, the implementation of modern medicine in remote rural or poor peri-urban African areas is limited. Especially in rural communities where there are few or no doctors, AHC or ATM are usually the primary source of medical care. Many local communities consider ATM as a complementary medical system. The activities of an AHC are supported by informal and formal primary caregivers that deliver extensive basic nursing services, such as physical, educational, psychological and spiritual care for both patients and their relatives [1]. 
In Africa, African Traditional Medicine (ATM) is believed to sometimes offer unsuspected efficacy where the practices of modern medicine fail or are powerless to supply treatment, particularly for routine ailments such as tropical diseases, allergies or psychiatric diseases. The spirit of ATM is human interaction using indigenous knowledge that is gained experientially, externalized and transmitted mostly through verbal expressions and gestures with some secret initiatic traditions [2]. At present, the practice of ATM is evolving; for instance, some urban Traditional Practitioners (TP) use conventional medicine facilities including medical tests for diagnosis and/or post-treatment checking [3]. However, this is not the generally reported experience, especially in rural communities throughout Africa.

Telemedicine is a sub-set of eHealth electronic process in health using information and communication technologies (ICT) for [4]:

- Teleconsultation, a procedure whereby medical professionals can consult a patient remotely and interpret the necessary data remotely. This consists of explanations and their rationale for suggested diagnosis and management plans with counseling in risk factor control and indications of treatment designed to reduce problem. After it is possible to make actions for medical followup.

- Medical Second Opinion Service or Teleexpertise, whereby a medical professional can seek remotely an opinion of other medical professionals who have the relevant training or skills. It allows people to obtain a valuable medical second opinion in the case of the diagnosis and treatment of non-critical and critical illnesses (e.g. skin and respiratory diseases, as well as nephrology disorders). This telemedicine service is intended to assist patients and their attending physician to improve healthcare outcome by a diagnostic revision and treatment enhancement.

- Telemonitoring, the ability to monitor and supervise patients remotely. The medical data can be obtained automatically on a pre-defined periodic basis (remote follow-up) or on a daily basis (remote monitoring) by the device which dispatches them from the patient's home to the medical doctor.

- Remote handling or Teleassistance, a procedure which enables a medical professional to assist remotely another healthcare professional during the realization of a medical act. This would correspond to two typical situations. First case: it may concern robotic telesurgery in which the expert surgeon performs the surgery form a distance through a robotic device. Second case: remote ultrasound examination in which the expert physician remotely directs the local ultrasonographer as to how to position the probe, and sometimes the expert may control the movements of a medical probe using ultrasonographic visualizations to perform useful assessments.

The objectives of telemedicine and its applications are to enhance the availability of various medical services and healthcare despite geographical and economic barriers, to reduce direct and indirect cost to patients and the healthcare industry, to save travel time and costs for both practitioners and patients from one geographical location to another, and to improve consultation and co-operation among various units of healthcare in both special cases and primary care by bridging the distance between practitioners and specialists $[5,6]$. There is an expectation that mobile phones will facilitate a range of telemedicine activities (cardiology, radiology, dermatology, obstetrics, psychiatry and ophthalmology) in Africa with a deep cultural immersion experience that generates a better understanding of local cultures' values, activities and prerequisites [7].

It is crucial to make this medical framework a systemic and very well locally integrated model by ensuring that practices are suited to the patient's belief and cultural environment. In primary care the concept "holistic", has been used to describe models that take into account social reflections and other contextual approaches [8]. Our research interest with telemedicine in Africa speaks most pointedly to this, as it indicates the possible way to embed the holistic concept into the management practices. As the informal and formal primary caregivers offer cultural and social insights to conventional medical staff (including information regarding local traditional medical activities), the cultural immersion they experience makes it easier for them to adapt allopathic medicine by integrating some cultural elements from ATM environment. Looking at it from the alternate aspect, these holistic medical practices play an important role for caregivers and patients in AHC, as they could use the facilities to stay in touch with their cultural background. Patient care tends to become more comprehensive when complementary medicine is integrated conventional healthcare organizations [9].

Traditional medicine is now offered alongside allopathic medicine at several locations in the African countries. Supply and distribution of medicinal products is mainly through the informal sector (e.g. traveling vendors of drugs (hucksters and peddlers), traditional health units or other informal drugstores). So, in these contextual situations, treatment is a broad concept and includes western, allopathic medicine as well as traditional medicine (complementary and alternative medicine). All these forms of conventional or traditional treatments, to some levels in their composition and properties, rely on natural substances, or elements synthesized from the natural environment.

The application of information and communication technologies can facilitate knowledge and information exchanges within the different actors with a view to improve patient health care services. It could stimulate information transfer in both directions, opens opportunities and improves experience feedbacks through possible useful collaborations and helps organize primary health care needs. Therefore this offers exceptional value to collaborative activities between informal and formal primary caregivers by creating networking opportunities, supporting and augmenting the visibility of initiatives that help sustain Western health and traditional practitioners' participation in efficient and safe practices.

\section{Proposed approach to eHealth (telemedicine and mHealth) in Africa}

According to World Health Organization (WHO) and International Telecommunication Union (ITU), eHealth (electronic 
process in health) is defined as "the use of information and communication technologies (ICT) for health" [10]. In particular, the applications of mHealth (mobile Health) and telemedicine are two sub-sets of eHealth as both involve the use of information and communications technology. These two applications have their own distinct features, varying in dimensions, deployments and configurations.

\section{Telemedicine in Africa}

In African countries, predominantly a great percentage of the people still live in rural regions and peri-urban areas, where healthcare access and delivery are sometimes reduced, and would possibly profit from advanced service schemes with supporting technical architectures and tools.

Tools such as telemedicine, tele-education, and health informatics have of late been incorporated in the health sector to enable easy access to essential services [11]. Training programmes and collaborative ways of working also contribute to fresh online services where teamwork between the official heath care actors and its community volunteers (with modern or traditional medical knowledge) takes a very new scope. The ICT work environment and associated workflow open doors and create opportunities for these formal and informal healthcare actors through unique sustainable programs [12]. Optimally used, the telemedicine would provide best practices and virtual learning facilities, especially with respect to AHC methods. For an optimum adaptation to the prevailing terrain conditions, telemedicine needs to incorporate flexibility with traditional symbols and teachings in the contextual health delivery schemes.

There is need to explain the constraints that generate some mismatches between Information System designs and local user actuality in developing countries [13]. It therefore appears desirable to provide the full range of along with counseling, to help primary caregivers obtain a method that best suits their necessities in both preventive and therapeutic activities. The idea is to facilitate access to the basic primary care - first-aid instruction, emergency response and medical information for communities who are isolated from appropriate medical institutions. It requires strategies to be means of guidance, training, support and long-term monitoring; or in the other sides to ensure information sharing to better understand a specific endemic situation and health system context. Patient information is best understood through the use of simple terminology, visual language (e.g. signs of cleansing and healing), readable images and the use of both scientific and vernacular names $[14,15]$. Due to remote solutions it is possible to reach optimally collective intelligence in collaborative actions between local health actors. The considered collaborative framework can include computerized guidelines for a group of local health actors. It may also be possible to combine this assistance with traditional medicinal knowledge that are evidence-based and integrate best practices in order to provide an understandable overview of the full nature and extent of the considered diseases and treatments for improvements in the contextual care system.

\section{Mobile health technology}

The mobile health (mHealth) technology is considered to refer to the incorporation of mobile computing, medical sensors, and portable devices to ensure health care [16]. Furthermore, mHealth affirms its interest further to investigate and to draw up an integration of the advances in wireless communication, ubiquitous computing and "wearable" devices technologies in the health area $[17,18]$.

The services of eHealth care actors are helping to address the issues of access, improvement of primary care, particularly for the most vulnerable people (e.g. the seniors' population) and undeserved communities in both developed and developing regions of the world [19]. More generally, the creative applications of remote health information and sensing technologies are potentially useful for checking health status, enhancing patient care and supporting service delivery. This includes different activities, namely measurement, diagnostic, treatment/prevention or the global healthcare [20]:

- Measurement: remote application enables statistical measurements, thresholds for alarms, environmental temporary assessment and global positioning system.

- Diagnostic: point-of-care diagnostics, graphics applications, remote analysis, sending of information on the patients' symptoms and signs for remote analysis, interpretation and diagnostics.

- Treatment/prevention: prevention and wellness interventions, remote behavioral treatment, medication adherence tracking, chronic disease management, dissemination of health information and disaster support/ care.

- Global healthcare: access to healthcare services, remote behavioral treatment, dissemination of health information, disease surveillance, medication tracking and safety and wellness intervention.

During the course of the last few years, there are a growing number of mHeath initiatives, but some of which will involve different application procedures. On the basis of comprehensive characteristics of employed terminology and their meaning, the World Health Organization (WHO) has proposed a classification of key research areas in mHealth [21]: Health call centers/Health care telephone help line, Toll-free emergency, Public health emergencies, Mobile telemedicine, Appointment reminders, Community mobilization \& health promotion, Patient records, Information initiatives, Patient monitoring, Health surveys, Surveillance, Awareness raising and Decision support systems.

The WHO's analysis provides an overview of adoption of mHealth initiatives and their implementation stages in America [22]. The survey indicates that the less wellestablished applications are the following classes: health surveys \& surveillance (e.g. through the implementation of the District Health Information Software (DHIS2) [23]), patient records, patient monitoring, decision support systems, treatment compliance and awareness raising. 
Table 1 Seven kind of mHealth initiatives [24].

\begin{tabular}{|c|c|c|}
\hline mHealth category & Fields of application & Description/practical use \\
\hline $\begin{array}{l}\text { Improving management and } \\
\text { decision-making by health } \\
\text { care professionals }\end{array}$ & $\begin{array}{l}\text { - Treatment of medical } \\
\text { conditions } \\
\text { - Prescriptions } \\
\text { - Targeted provision of } \\
\text { information and marketing } \\
\text { about health care products }\end{array}$ & $\begin{array}{l}\text { - Remote patient tracking } \\
\text { - Updating and verification of digital medical records, } \\
\text { accessible to health care providers and pharmacists } \\
\text { - Delivery of health insurance and savings products }\end{array}$ \\
\hline $\begin{array}{l}\text { Real-time and location-based } \\
\text { data gathering }\end{array}$ & $\begin{array}{l}\text { - Health care delivery and } \\
\text { logistics } \\
\text { - Crisis mapping } \\
\text { - Resource allocation }\end{array}$ & $\begin{array}{l}\text { - Monitoring and surveillance of disease outbreaks for } \\
\text { more timely reporting of symptoms and containment } \\
\text { of epidemics } \\
\text { - Crisis mapping after natural disasters } \\
\text { - Reporting of urgent health needs } \\
\text { - Real-time provision with information on available } \\
\text { health facilities and resources } \\
\text { - Supply chain management } \\
\text { - Access to health emergency services and rapid } \\
\text { response systems }\end{array}$ \\
\hline $\begin{array}{l}\text { Provision of health care to } \\
\text { remote and difficult-to-serve } \\
\text { locations }\end{array}$ & $\begin{array}{l}\text { - Remote provision of health } \\
\text { care services } \\
\text { - Extending the reach of } \\
\text { health care } \\
\text { - Complementing traditional } \\
\text { face-to-face health care } \\
\text { services }\end{array}$ & $\begin{array}{l}\text { - Medical advice, reminders counseling, monitoring, } \\
\text { simple diagnoses } \\
\text { - Focusing on areas where only limited physical } \\
\text { infrastructure is available, such as remote and rural } \\
\text { areas, including telenursing, teleradiology, } \\
\text { telepsychiatry, and tele-education. }\end{array}$ \\
\hline $\begin{array}{l}\text { Fostering learning and } \\
\text { knowledge exchange among } \\
\text { health professionals }\end{array}$ & $\begin{array}{l}\text { - Medical knowledge repositories } \\
\text { - Virtual communities } \\
\text { - Event and conference } \\
\text { organization }\end{array}$ & $\begin{array}{l}\text { - Retrieving best practices, international standards, } \\
\text { and patient histories from other health care } \\
\text { professionals } \\
\text { - Local communities } \\
\text { - Expert crowdsourcing for health information wikis } \\
\text { - Virtual classrooms, webinars, and the like }\end{array}$ \\
\hline Promoting public health & $\begin{array}{l}\text { - Delivery of health information } \\
\text { - Awareness building and } \\
\text { campaigning } \\
\text { - (Mass-oriented) tele-education }\end{array}$ & $\begin{array}{l}\text { - Games, quizzes, and other nontraditional } \\
\text { mechanisms } \\
\text { - Conventional mHealth prevention and education } \\
\text { campaigns } \\
\text { - Medication reminders }\end{array}$ \\
\hline Improving accountability & $\begin{array}{l}\text { - Transparency for usage of funds } \\
\text { - Feedback systems }\end{array}$ & $\begin{array}{l}\text { - Public health fund flow tracking } \\
\text { - Interactive portals for comments and complaints }\end{array}$ \\
\hline $\begin{array}{l}\text { Self-management of patient } \\
\text { health }\end{array}$ & $\begin{array}{l}\text { - Enabling better self-help and } \\
\text { limiting transactions } \\
\text { - Lowering health care costs } \\
\text { (shifting tasks to the patient) } \\
\text { - Patient empowerment }\end{array}$ & $\begin{array}{l}\text { - Patients obtain accurate information } \\
\text { - Patients can better understand their diagnoses, for } \\
\text { example, by checking medical records } \\
\text { - Mainly focused on noncommunicable diseases and } \\
\text { may deal with health indicators such as weight and } \\
\text { blood pressure }\end{array}$ \\
\hline
\end{tabular}

A recent report of the World Bank has classified mHealth initiatives in developing countries into the seven distinct categories described in Table 1.

Some studies of selected mobile health deployments in Africa have been added, and summarized in Table 2 emphasizing their main specificities.
There are also different projects for screening and treatment aided by the use of telemedicine established in some developing countries (e.g. mobile diabetic retinopathy screening and treatment models in India [26]), which can be readily replicated in African countries presented with similar difficulties. 
Table 2 Selected mobile health deployments in Africa [25].

\begin{tabular}{|c|c|c|c|}
\hline Country & Provider & Project & Outline \\
\hline Mali & Medic Mobile & FrontlineSMS & $\begin{array}{l}\text { An SMS platform that is used for patient management. The services } \\
\text { include accessing of Electronic Health Records through mobile } \\
\text { phones, low cost diagnostics and mapping of health services. }\end{array}$ \\
\hline Ghana & $\begin{array}{l}\text { Vodafone, Ghana } \\
\text { Medical Association }\end{array}$ & MDNet & $\begin{array}{l}\text { A free voice and sms services that promotes transfer of knowledge } \\
\text { among physicians. This service helps to send bulk SMS during national } \\
\text { emergencies and contact doctors with particular speciality. }\end{array}$ \\
\hline Nigeria & We Care Solar & WE CARE Solar & $\begin{array}{l}\text { WE CARE Solar's project attempts to promote safe motherhood and } \\
\text { reduce maternal mortality in developing regions. This project } \\
\text { provide health workers with reliable lighting, mobile } \\
\text { communication, and blood bank refrigeration using solar electricity. } \\
\text { The provision of mobile phones allows labor and delivery nurses to } \\
\text { quickly notify on-call physicians of emergencies, and ask for advice. }\end{array}$ \\
\hline Kenya & Dimagi & Weltel & $\begin{array}{l}\text { SMS service to support antiretroviral medication adherence. It helps } \\
\text { health worker assist HIV patients and provides health information to } \\
\text { the public. It also includes support for remote data collection and } \\
\text { logistics of moving healthcare related products. }\end{array}$ \\
\hline Mozambique & $\begin{array}{l}\text { Canadian International } \\
\text { Development Agency }\end{array}$ & AED Satellite & $\begin{array}{l}\text { CHWs use PDAs and mobile phones for data collection and access to } \\
\text { up to date health information }\end{array}$ \\
\hline Botswana & $\begin{array}{l}\text { American Academy of } \\
\text { Dermatology }\end{array}$ & $\begin{array}{l}\text { Africa Tele- } \\
\text { dermatology } \\
\text { Project }\end{array}$ & $\begin{array}{l}\text { Telemedicine for dermatology. Provides dermatology support to local } \\
\text { physicians, dermatologists, and health care workers in hospitals and } \\
\text { clinics throughout Africa. This support is provided through } \\
\text { Teledermatology consultation services, discussion pertaining to } \\
\text { diagnosis and management of patients with skin diseases, links to } \\
\text { educational resources, and access to a dermatologic curriculum } \\
\text { created specifically for African sites. }\end{array}$ \\
\hline
\end{tabular}

Given the shortage of corroborations about the scope and the impact of the mobile phone research programs concentrated on health purposes [27], the data from some recent studies may aid health professionals and those responsible for implementing programs and technical conditions to measure the utility or value of reaching African people via mobile phone [28].

\section{Discussion}

In the foreseeable future, we hope that telehealth solutions could enhance AHC or ATM practices and facilitate the complementary delivery of both modern and traditional healthcares with evident added value to the recipients.

In principle, there are two ways in which the use of telemedicine can help promoting the understanding and establishment of communication between African traditional medicine practitioners and doctors providing Western medicine:

(i) either in a direct way through political integrative medicine actions for rural communities that create opportunities to integrate traditional and allopathic healthcare issues;

(ii) or in an indirect way through a network of primary-care actors acting as bedside intermediaries between the allopathic health practitioners and the African traditional practitioners.
Therefore, the emergence of telemedicine can be seen as an opportunity for national health authorities to renew knowledge for medical policy-making and actions in response to the need to improve health care services (quality and safety) for rural communities. The major problem which is making a huge negative impact on Africa's telecommunications today is the high cost of bandwidth and this in turn affects connectivity for an effective electronic network in order to provide rural telemedicine solutions in Africa.

More effective and transparent price ICT (as mobile phone and Internet services) is needed in order to deliver the full advantages of advanced information technology infrastructures to African people. In this context, the technological progresses shall be accompanied by a better understanding of the wide-area of social science research on health in Africa. In a great many situations, compared to traditional communication means, telemedicine could potentially play an important role in developing countries, for improvements in traditional health systems and the use of news ICT to inform general populations on health and healthcare [29].

Despite their apparent promise, advanced health information technologies have proved difficult to implement in rural African settings, since there are some local technical difficulties (e.g. Internet access limited to the minority of people) caused by the delay in delivery or unavailability of mobile communication network equipments and handsets, optical transmission equipments and communication cables and cultural constraints (e.g. challenges posed by a large number of indigenous African languages). The costs and infrastructural difficulties have limited the penetration of 
$3 \mathrm{G}$ services in rural areas of African countries. They are in fact two of the Asia's leading companies in telecommunications (India's Bharti Airtel and Japan's Softbank Corp), which are working together to engineer new cost-effective solutions using satellites to increase $3 \mathrm{G}$ coverage on African continent and to make satellite $3 \mathrm{G}$ transmission more viable [30], resulting in fewer difficulties and more opportunities for the various remote services to rural areas of Africa.

The evolution of the telecentre movement with sustainability considerations have generated various types of public ICT access centers in developing countries: initiatives such as the Internet café or cybercafé, Internet kiosks, Community Multimedia Centers, and 'private hucksters phone booth' have conveyed the reality of the Internet and ICT closer to more persons in developing countries [31]. The mobile phone is the ICT of choice in the sub-Sahara [32]. Sharing mobile phones are more common in developing countries (partly for cultural and economic reasons) and this sharing has some implications for the digital divide that is greatly reduced in mobile phones [33]. So, the mobile phone use in Africa offsets the inequality in mobile phone adoption and mobile penetration rate [34]. The use of shared tools for mHealth implementation require an effective strategy by the health regulators to ensure the protection of privacy and personal data, regardless of the technology used to deliver a particular medical service. This can be done through the introduction of coordinated instruments (economic and technical assistance, social dialogue and legislation) or the development of existing ones for deployment and controlling the application of operating procedures and practices. Pending resolution of the outstanding issues, the first applications of the telemedicine management services are expected to be education and counseling medical services for people in rural African regions.

There are two possible mechanisms of access to the Internet in rural areas of developing countries: one that involves intermediation at a distance (blending) and the other that takes place at close range (via say Internet kiosks) [35]. Internet access in community multimedia centers, and other fixed or mobile telecentres in public or private places offer a low cost opportunity for the people who cannot afford their own phone or Internet connection [36]. Provincial urban hubs could at that moment be points of dissemination of health information to the rural areas [37]. Levi Obijiofor describes a research-based framework for the analysis of the successful diffusion and use of ICTs at micro and macro levels in Africa; so he provides practical issues in the uptake of new technologies in different countries and communities [38]. Ousmane Birba and Abdoulaye Diagne have developed a survey (covering 17 African countries) about factors explaining the adoption of Internet with determinants that favor or hamper the use of Internet in Africa. Their study also suggests that a rural individual can probably use Internet if he has at least completed primary education [39]; but this is subject to Internet availability and verification of connectivity. The ICT divide is not defined as much by the economic status of a geographic location as it is by an individual user's educational background [40]. Furthermore, wireless technologies present great potential to reach unserved and underserved areas [41].

There was a broad consensus that many of the legal and ethical issues (security, confidentiality and privacy) arising from the practice of eHealth have not been resolved in general [42]. Particularly, telemedicine creates new clinical risks and responsibilities that are associated to product liability and safety issues [43]. Hence, there are some needs of a rigorous application of available guidelines and the legal resolution of the pending issues (lack of reimbursement, safety and quality of care, privacy, human dignity and rights) [44].

Finally, the main challenge is moving mHealth approaches from pilot projects to national scalable programs while accurately engaging health workers and communities in the development [45].

\section{Conclusion}

ICT has a major role to play in generating the availability and accessibility of care facilities for rural communities. In fact, ICT applications have great potential to benefit lower isolated groups and other disadvantaged populations through the elaboration of specific small progress in the efficiency of the health care delivery system, including improvements in primary health care provisions. The influence stems in large part from the availability of prepaid Internet services, coupled with the development of mobile payphone services. The integration of remote expertise in healthcare has significant benefits for patient management in remote locations or precarious areas or situations. Periodic reviews of contextual requirements and advanced benchmarks will take place to provide the information to improve telemedicine or healthcare programs knowledge. The gained knowledge could guide the deployment of new network technologies with a long-term perspective of diagnostic/prescription system prototypes in order to improve disease surveillance and monitoring of ATM products or others drugs.

By improving their medical knowledge, primary caregivers we will be better able to target the disease and adapt treatment to achieve the best results and good safety. Telemedicine in $\mathrm{AHC}$ fosters a better understanding of the special needs of rural patients and primary caregivers, in addition to providing healthcare delivery organizations with reasonable access to traditional knowledge and vital information about sustainable use of natural resources. From a technology acceptance view, human factors and adoption by end users (determined by attitude, perceived usefulness, and perceived ease of use) is a key restrictive factor to successful ICT adoption in developing countries [46]. So more understanding of the current human environment in working out some knowledge-based applications that would meet the ICT prerequisites of the primary health sector in Africa is essential. The deployment of assessment studies that integrate the accessibility of technology and end-user preference is a significant human factor that should be measured in developing an appropriate ICT implementation strategy in low-resource settings [47].

The deployment of new technologies and sustainable medical practices continue to be hampered by logistical factors (e.g. the poor availability of communication equipments and terminal products or the delivery of electricity is unreliable owing to frequent power outages) as well as by organizational factors (e.g. weak human resource and 
management capacities) that may also be affected by general cultural, political and economic considerations (e.g. the debt burden on the national economy prevents sufficient spending on rural health program). Hence, the advances in technology need to be accompanied by the development of effective delivery mechanisms (e.g., using evidence-based intervention strategies) and novel organizational approaches (e.g., assistance in integrating the system into practice workflows and allowing for local customization) with sustainable implementations (e.g., targeting actionable priority issues for patients and healthcare teams) [48-50]. Telemedicine could bring the best of sophisticated approaches and latest medical expertise in African Home-based Care (AHC) and permit to share and formalize African traditional medicine. The principles of providing health information feedback to frontline health staffs and community-based organizations are fundamental to support decentralized medical activities in remote areas [51-61].

\section{Ethical approval}

Not required.

\section{Funding}

This research was not supported by any funding.

\section{Competing interests}

None declared.

\section{References}

[1] Mashiri M, Maponya G, Nkuna Z, Dube S, Chakwizira J. PG report: rural accessibility \& development, unpacking the relationship between rural healthcare, mobility \& access. Pretoria: CSIR; March 31, 2007.

[2] Cumes David. South African indigenous healing: how it works. Explore: J Sci Heal 2013;9(1):58-65.

[3] Hillenbrand E. Improving traditional-conventional medicine collaboration: perspectives from Cameroonian traditional practitioners. Nord J Afr Stud 2006;15(1):1-15.

[4] Simon P, Williatte Pellitteri L. Le décret français de télémédecine: une garantie pour les médecins. Eur Res Telemed 2012;1(2):70-5.

[5] Lareng Louis. Telemedicine in Europe. Eur J Intern Med 2002;13(1):1-3.

[6] Lareng L. Telemedicine: greatness and sadness. Eur Res Telemed/La Rech Eur Téléméd 2013;2(2):79-80.

[7] Mars Maurice. Telemedicine and advances in urban and rural healthcare delivery in Africa. Prog Cardiovasc Dis 2013;56 (3):326-35.

[8] Hart Julian Tudor. The political economy of health care; 2010. p. 106, 258.

[9] Keshet Y, Ben-Arye E, Schiff E. Can holism be practiced in a biomedical setting? A qualitative study of the integration of complementary medicine to a surgical department Health (Lond) 2012;16(6):585-601. http://dx.doi.org/10.1177/ 1363459312438566.

[10] WHO and ITU: National eHealth Strategy Toolkit; 2012 [cited 18 January 2013]. Available from: 〈http://goo.gl/uxMvE〉.

[11] Wamala DS, Augustine K. A meta-analysis of telemedicine success in Africa. J Pathol Inform 2013;4:6.
[12] Barjis Joseph, Kolfschoten Gwendolyn, Maritz Johan. A sustainable and affordable support system for rural healthcare delivery. Decis Support Syst 2013;56:223-33.

[13] Heeks R. Information systems and developing countries: failure, success, and local improvisations. Inf Soc 2002;18:101-12.

[14] Kamsu-Foguem Bernard, Diallo Gayo, Foguem Clovis. Conceptual graph-based knowledge representation for supporting reasoning in African traditional medicine. Eng Appl Artif Intell 2013;26(4):1348-65.

[15] Kamsu-Foguem Bernard, Foguem Clovis. Adverse drug reactions in some African Herbal medicine: literature review and stakeholders' interview. Integr Med Res 2014, http://dx.doi. org/10.1016/j.imr.2014.05.001 (in press).

[16] Istepanian R, Jovanov E, Zhang Y. Guest editorial introduction to the special section on $\mathrm{m}$-health: beyond seamless mobility and global wireless health-care connectivity. IEEE Trans Inf Technol Biomed 2004;8:405-14.

[17] Abajo B, Rodrigues J, Salcines E, Fernandez J, Coronado M, Lozano C. m-Health y T-Health, La Evolucicion Natural del E-Health, in: RevistaeSalud.com, vol. 7; 2011.

[18] Tachakra S, Wang X, Istepanian R, Song Y. Mobile e-Health: the unwired evolution of telemedicine. Telemed e-Health 2003;9:247-57.

[19] Iwaya LH, Gomes MAL, Simplício MA, Carvalho TCMB, Dominicini CK, Sakuragui RRM, et al. Mobile health in emerging countries: A survey of research initiatives in Brazil. Int J Med Inform 2013;82(5):283-98.

[20] Kumar Santosh, Nilsen Wendy J, Abernethy Amy, Atienza Audie, Patrick Kevin, Pavel Misha, et al. Mobile health technology evaluation: the mHealth evidence workshop. Am J Prev Med 2013;45(2):228-36.

[21] WHO, mHealth. New horizons for health through mobile technologies: second global survey on eHealth. The World Health Organization (WHO); 2011.

[22] E. Institute. Barriers and gaps affecting mhealth in low and middle income countries: a policy white paper. Washington, DC: mHealth Alliance; 2010.

[23] Aksel Sanner Terje, Kristian Roland Lars, Braa Kristin. From pilot to scale: towards an mHealth typology for low-resource contexts. Health Policy Technol 2012;1:155-64.

[24] World Bank, maximizing mobile, information and communications for development, IC4D-2012-Report; 2012. Available online at: 〈http://siteresources.worldbank.org/EXTINFORMA TIONANDCOMMUNICATIONANDTECHNOLOGIES/Resources/ IC4D-2012-Report.pdf〉.

[25] GSMA/PwC Report: touching lives through mobile health: assessment of the global market opportunity, February 2012, Report, GSMA. Available online at: 〈http://www.gsma.com/ connectedliving/wp-content/uploads/2012/03/gsmapwctou chinglivesthroughmobilehealthreport.pdf $\rangle$.

[26] Murthy Krishna R, Murthy Praveen R, Kapur Anil, Owens David R. Mobile diabetes eye care: experience in developing countries. Diabetes Res Clin Pract 2012;97(3):343-9.

[27] Gurman TA, Rubin SE, Roess AA. Effectiveness of mHealth behavior change communication interventions in developing countries: a systematic review of the literature. J Health Commun 2012;17(Suppl 1):82-104.

[28] Vahdat Heather L, L’Engle Kelly L, Plourde Kate F, Magaria Loice, Olawo Alice. There are some questions you may not ask in a clinic: providing contraception information to young people in Kenya using SMS. Int J Gynecol Obstet 2013;123 (Suppl 1):e2-6. http://dx.doi.org/10.1016/j.ijgo.2013.07.009.

[29] Lucas Henry. Information and communications technology for future health systems in developing countries. Soc Sci Med 2008;66(10):2122-32.

[30] IBTimes. Rural Africa, meet 3G: Asian telecoms using satellites to increase coverage on continent. International Business Times, By IBTimes Staff Reporter on August 292013. 
Available at: 〈http://www.ibtimes.com/rural-africa-meet-3 g-asian-telecoms-using-satellites-increase-coverage-conti nent-1401623/> [last accessed on 20 May 2014].

[31] Fillip B, Foote D. Making the connection: scaling telecentres for development. Washington, DC: Academy for Educational Development, with Telecentre.org and Microsoft; 2007.

[32] Alozie Nicholas O, Akpan-Obong Patience, Foster William A. Sizing up information and communication technologies as agents of political development in sub-Saharan Africa. Telecomm Policy 2011;35(8):752-63.

[33] James Jeffrey. Sharing mobile phones in developing countries: implications for the digital divide. Technol Forecast Soc Change 2011;78(4):729-35.

[34] James Jeffrey. Product use and welfare: the case of mobile phones in Africa. Telemat Inform 2014;31(3):356-63.

[35] James Jeffrey. Mechanisms of access to the Internet in rural areas of developing countries. Telemat Inform 2010;27 (4):370-6.

[36] Henten A, Falch M, Anyimadu A. Telecommunications development in Africa. Telemat Inform 2004;21(1):1-114.

[37] Ajuwon GA, Rhine L. The level of Internet access and ICT training for health information professionals in sub-Saharan Africa. Health Info Libr J 2008;25(3):175-85.

[38] Obijiofor Levi. Mapping theoretical and practical issues in the relationship between ICTs and Africa's socioeconomic development. Telemat Inform 2009;26(1):32-43.

[39] Birba Ousmane, Diagne Abdoulaye. Determinants of adoption of Internet in Africa: case of 17 sub-Saharan countries. Struct Change Econ Dyn 2012;23(4):463-72.

[40] Dutta Renee. Information needs and information-seeking behavior in developing countries: a review of the research. Int. Inf Libr Rev 2009;41(1):44-51.

[41] Fosu Ignatius. Exploring the potential of wireless technologies to accelerate universal Internet access in Ghana. Telecomm Policy 2011;35(6):494-504.

[42] Kluge Eike-Henner W. Ethical and legal challenges for health telematics in a global world: telehealth and the technological imperative. Int J Med Inform 2011;80(2):e1-5.

[43] Stanberry Benedict. Legal ethical and risk issues in telemedicine. Comput Methods Programs Biomed 2001;64(3):225-33.

[44] Siegal Gil. Telemedicine: licensing and other legal issues. Otolaryngol Clin North Am 2011;44(6):1375-84.

[45] Källander K, Tibenderana JK, Akpogheneta OJ, Strachan DL, Hill Z, ten Asbroek AHA, et al. Mobile Health (mHealth) approaches and lessons for increased performance and retention of community health workers in low- and middle-income countries: a review. J Med Internet Res 2013;15(1):e17.

[46] Glasgow Russell E, Phillips Siobhan M, Sanchez Michael A. Implementation science approaches for integrating eHealth research into practice and policy. Int J Med Inform 2014;83(7): e1-11. http://dx.doi.org/10.1016/j.ijmedinf.2013.07.002.

[47] Jimoh Lanrewaju, Pate Muhammad A, Lin Li, Schulman Kevin A. A model for the adoption of ICT by health workers in Africa. Int J Med Inform 2012;81(11):773-81.

[48] Glasgow Russell E. eHealth evaluation and dissemination research. (Supplement). Am J Prev Med 2007;32(5):S119-26.

[49] Howitt Peter, Darzi Ara, Yang Guang-Zhong, Ashrafian Hutan, Atun Rifat, Barlow James, et al. Technologies for global health. Lancet 2012;380(9840):507-35.

[50] Abbott Patricia A, Foster Joanne, Marin Heimar F, Dykes Patricia C. Complexity and the science of implementation in Health IT knowledge gaps and future visions. Int J Med Inform 2014;83(7): e12-22. http://dx.doi.org/10.1016/j.ijmedinf.2013.10.009.

[51] Madon Shirin, Olanya Amaguru Jackline, Ntuli Malecela Mwele, Michael Edwin. Can mobile phones help control neglected tropical diseases? Experiences from Tanzania. Soc Sci Med 2014;102:103-10.

[52] Doumbouya MB, Kamsu-Foguem B, Kenfack H, Foguem C. Telemedicine using mobile telecommunication: towards syntactic interoperability in teleexpertise. Telemat Inform 2014;31(4):648-59.

[53] Bernard Kamsu-Foguem. Systemic modeling in telemedicine. Eur Res Telemed 2014;3(2):57-65.

[54] Bernard Kamsu-Foguem. Ontological view in telemedicine. Eur Res Telemed 2014;3(2):67-76.

[55] Kamsu-Foguem B, Tchuenté-Foguem G, Allart L, Zennir Y, Vilhelm C, Mehdaoui $\mathrm{H}$, et al. User-centered visual analysis using a hybrid reasoning architecture for intensive care units. Decis Support Syst 2012;54(1):496-509.

[56] Kamsu-Foguem B, Tchuenté-Foguem G, Foguem C. Conceptual graph operations for formal visual reasoning in the medical domain. IRBM 2014. http://dx.doi.org/10.1016/j.irbm.2014. 04.001.

[57] Kamsu-Foguem B, Tchuenté-Foguem G, Foguem C. Using conceptual graphs for clinical guidelines representation and knowledge visualization. Inform Syst Front 2014;16(4):571-89.

[58] Kamsu-Foguem B, Foguem C. Could telemedicine enhance traditional medicine practices? Eur Res Telemed 2014. http://dx.doi. org/10.1016/j.eurtel.2014.08.001.

[59] Kamsu-Foguem B, Tchuenté-Foguem G, Foguem C. Verifying a medical protocol with temporal graphs: The case of a nosocomial disease. J Criti Care 2014;29(84):690.e1-9.

[60] Tafin-Kampé K, Kamsu-Foguem B. Acute osteomyelitis due to Staphylococcus aureus in children: What is the status of treatment today? Pediatr Infect Dis 2013;5(3):122-6.

[61] Tafin-Kampé K. Vitamine D et personnes âgées : enquête auprès de 192 médecins généralistes dans les Hautes-Pyrénées. NPG Neurol Psychiatr - Gériatr. 2014;14(82):221-7. 